\title{
The key factors in transforming Birjand City to a smart city: smart mobility, smart government
}

\author{
Amirhossein Ghasemi, Mohsen Saberi
}

Department of Engineering, Bozorgmehr University of Qaenat, Iran

\begin{tabular}{l}
\hline \hline Article Info \\
\hline Article history: \\
Received Jul 16, 2019 \\
Revised Dec 2, 2019 \\
Accepted Dec 25, 2019 \\
\hline
\end{tabular}

\section{Keywords:}

Birjand

Content analysis

Intelligent transportation

system

Rules and regulations

Smart government

SWOT

\begin{abstract}
The physical development of urban communities and cities, as well as the advancement of communication and information world, increased the need for advanced technologies. Nowadays, many urban planners and managers, especially the mangers of the intelligent transportation system and smart government, are concerned with the transformation of physical cities to electronic cities and finally build smart cities in the real world. Making electronic cities smart requires the full participation of urban management organizations in different sectors. This study aimed to investigate the key factors in transforming Birjand city into a smarter city by focusing on two components of the intelligent transport system and smart government. In smart government, a structure is recommended that is appropriate for launching and preparing the policies and regulations that need to be covered by different dimensions. And it also intends to introduce the principles and dimensions of the intelligent transportation system and explore the potentials and strategic planning opportunities in Birjand city using a descriptive-analytical method. The data were collected by the library - documentary method. Furthermore, the study was conducted as field-survey research (interviews and questionnaires). In continuation, the strengths and weaknesses, opportunities and threats (SWOT) of the intelligent transportation system were determined and analyzed using the SWOT strategic planning model. Finally, appropriate strategies were presented.
\end{abstract}

Copyright (C) 2020 Institute of Advanced Engineering and Science. All rights reserved.

\section{Corresponding Author:}

Amirhossein Ghasemi, Department of Engineering, Bozorgmehr University of Qaenat, Iran.

Email: ghasemi@buqaen.ac.ir

\section{INTRODUCTION}

Iran is blessed with a variety of astonishing urban design, among which are smart urbanism and cities [1]. Birjand was the first city of Iran that had the water supply organization. And later on it became a charity organization and it named Ablole Water Pipeline organization, that it became the first water supply charity organization in Iran. This is known to be the second city in Iran, which was acquired in 1302 and before Tehran from urban water plumbing. The "akbariyeh Garden," one of the historic buildings of this city that were registered at the UNESCO World Herald's 23rd UNESCO World Heritage Summit in 2011 [2]. Shokatiyeh School in this city became the third school of modern education, training, next to Darolfonon in Tehran and Rashdieh in Tabriz. The second largest airport in the country after the gleh Moghimi and Bushehr was built in 1312 due to the political and strategic position in Birjand. Until the Second World War, Russian and British consulates were operating in Birjand [2, 3].

At 1997, World Forum on Smart Communities, it was estimated that some 50,000 cities and town around the world would embrace "smart" initiatives by the year 2000 [4]. By 2050, the United Nations estimate 
53\% (fifty-three percent) of the population will live in urban [5]. Smart cities represent a conceptual urban development model on the basis of the utilization of human, collective, and technological capital for the development of urban agglomerations [6] Recently, the concept of Smart City has emerged as a way to "exploit the information and communication technologies (ICT) in making better use of the public resources, increase the quality of services offered to the citizens and, in turn, the quality of life in urban areas, while reducing the operational costs of the public administrations" [6]. Globally, cities are already implementing smart initiatives in providing better services for citizens, businesses, employees, and governments [7]. The American car culture began to form during the early 20th century. The first three-colored traffic signal was deployed in 1914, and the first parking meter was installed in 1935. The 1950s brought research into ramp management techniques as a potential solution to highway safety concerns. The first North American traffic management centers (TMCs) were deployed in the late 1960s. The global positioning system (GPS) consists of a network of satellites that transmit signals to GPS receivers. During the 1980s, major changes appeared to be on the horizon. During the 1980s, in the midst of these concerns, technology became cheaper and smarter and technologies supporting improved traffic management emerged [8].

In recent years, the rapid growth of population and urbanization, as well as the increase in the number of vehicles, caused many problems, including pollution, heavy traffic, and accidents in the transport sector. Due to the geographical location of Birjand and its distance from other large cities such as Mashhad and Zahedan, and also due to its conversion to the capital of the province, the need to transform the urban structure from traditional to Modern and smart state is felt more and more. Challenges associated with e-government and must provide different levels of communication and dynamic environment full of tools and applications interact $[9,10]$. With the emergence of new sources of information, technologies like big data, open data, social networks, blogs, mobile government, cloud computing, and other cases, the service has drastically changed.

Actions such as smart cards of interurban bus fleets, speed control cameras and violations, public electronic communication systems with urban managers far too few have been done in Birjand city. However, these actions don't meet the needs of citizens due to the scope of intelligence-related areas [11-13]. Khiabani et al. have conducted many research on Design and implementation of an optimal switching controller which could come in handy in designing smart cities [14-16]. Azarang et al. have studied on a new fractional-order chaotic system and its synchronization via Lyapunov and improved Laplacian-based method [17-19]

Ambient Street Lighting project was developed by Mohamed [20], using embedded-based Arduino microcontroller for lighting management based on the circumstances surrounding of the road. A threshold value is set based on a reading of the actual situation in order to test the functionality of the prototype. The Ambient Street Lighting prototype have reacted with success towards surrounding brightness/darkness and number of cars passing by on the street. Many scientists have studied their cities [21,22] and smart homes [23] on the subject of whether or not they are smart, which part corresponds to the conventional indicators of smart place, what factors hinder the further development in this direction and which steps should be taken. A real-time system is an attractive topic for both academic and industrial sections. Therefore, a wide variety of systems have been researched and created for different aspects of life like automated construction progress [24], intenet of things (IOT) system [25-27], Human-Robot Teaming [28-30], simulation [31], and so on. This study aimed to identify the requirements and needs of smart government and intelligent transport system (ITS) in Birjand city and design a suitable structure for it. Also, the study intends to analyze the policies and regulations related to the development of e-government and intelligent transport systems (ITS) since they include the six suggested dimensions i.e. Smart economy, smart citizen, smart government [32, 33], smart transportation, smart environment, and smart living. One of the newest and most effective traffic management solutions resulted from information technology is public transport development along with the use of intelligent transport systems.

Therefore, some of the reasons for making Birjand into a smart city can be referred to as the following:

a) Its extent and relation to shipping and transit costs

b) Sustainable development due to inefficient transport and dispersed city leading to increased fuel and violation of sustainable development patterns

c) Increased staggering costs for energy carriers (gas, water, and electricity)

d) The heavy cost of providing urban infrastructures and the development of information technology

Here, we try to have a thorough look at the goals of various generations of e-government:

a) The first generation: computerization of government and the improvement of computer-assisted efficiency

b) The second generation: the transition to an integrated and citizen-based government. Here, the goal is government open ness to people and innovation in sovereignty.

The third-generation: it is based on ICT and is introduced as the emerging model. The government seeks to innovate in the policy process and increase efficiency and effectiveness. The important elements of this generation are data, information, and knowledge. 


\section{RESEARCH METHOD}

In this study, the descriptive-analytic method was used to achieve research goals. The data were collected by the library-documentary method and the study was conducted as field-survey research. Firstly, interviews were conducted with related people in urban transport and smart government. In the next step, the experts, as well as Ph.D. And Master's students, were consulted in preparing a questionnaire with the help of experts. Then, the collected data were analyzed by SWOT's strategic planning model and the strengths, weaknesses, opportunities, and threats of sustainable transport development and smart government in Birjand city were specified. For more information, the analysis steps and SWOT's strategic model used in this study are as the following.

\subsection{SWOT analysis}

The SWOT analysis was first introduced by two Graduates from the Harvard Business School named George Albert Smith and Roland Christensen during the early 1950s [34]. Then this analysis gained more and more achievements and became known as a useful management tool. However, the most visible success of this analysis was when Jack Welch (chairman and CEO of General Electric) used this analysis in the 1980s to investigate GE's strategies and increase the productivity of his organization. SWOT is an acronym for strengths, weaknesses, opportunities, and threats. The first step in strategic planning process is to determine the goals and missions of the organization. Then, the appropriate strategies can be designed for the organization by using SWOT analysis, which is one of the tools for the strategic development. This analysis not only makes possible to analyze internal and external environments but also chose to make strategic decisions that balance the strength of the organization with environmental opportunities.

\subsection{Quantitative SWOT analysis}

The quantitative SWOT analysis provides more detailed data for SWOT analysis. This method corresponds to the MADM decision-making method which uses multi-layer designs to simplify complex problems and can run SWOT analysis simultaneously on several organizations. The complication of planning processes by multiple criteria may be due to the fact that SWOT has not been properly. This indicates that an unspecified, qualitative and incomplete list of influential factors of the internal and external environment have been used in the organization. Among the methods that use SWOT analysis are external factor evaluation matrix (EFE), internal factor evaluation matrix (IFE) and the competitive scheme matrix (CPM). However, the following shortcomings are unavoidable in all of these methods:

a) The ranking of the main factors is done objectively. Therefore, all of these methods have difficulty in ranking quantitative data like turnovers.

b) In the objective ranking of data, evaluators rank data without testing. This may result in a lack of integrity between the data.

To obviate these problems, Kurttila et al. \& Stewart, et al [35] combined analytic hierarchy process AHP with SWOT analysis. They invented a new hybrid approach to improve the analysis in the SWOT method. In some cases, they developed SWOT analysis based on t-GSM strategy matrix.

\subsection{Proposed method}

The structure presented in this section for the intelligent government in Birjand is a combination of the structures of Scholl [36], along with other important components. The proposed structure for identifying needs and important requirements for the realization and deployment of the intelligent government, consists of two important layers that are at the core of this structure of citizens, because the state's most important goal Smart is to improve the quality of life of citizens by providing quality services, identifying their needs prior to announcing their needs and fulfilling them, and cooperating actively with citizens in different fields. As mentioned above, the proposed structure consists of two layers, in the first layer, three components of technology, supply and application, and institutions, and the second layer consists of governance/policy components, intelligent economy, infrastructure, intelligent community and Intelligent environment. It is worth noting that the first layer includes components that directly connect with the citizen and provide services to him, while the second layer consists of components that, although not directly related to the citizen, provide the appropriate framework for providing quality services and To bridge their needs and problems. All components of the proposed structure have two-way communication and interaction.

\section{RESULTS AND DISCUSSION}

The SWOT strategic planning model was used for potentiometric analysis as well as an advantage and disadvantage analysis of intelligent transport system in Birjand city. In this type of analysis, the suggested strategies should maximize the strengths and minimize the opportunities. Consequently, if this logic is used 
correctly, it will have very good results to select and design an effective strategy [37]. To formulate the final strategies, it is necessary to consider all factors as part of the strategic planning process within the framework of the SWOT analysis model. Generally, the SWOT technique is a tool for analyzing the situation and formulating strategies. This is carried out by:

a) Recognizing and classifying the strengths and weaknesses;

b) Recognizing and classifying opportunities and threats outside of the system;

c) Determining the strategic position and developing a SWOT matrix;

d) Formulating various strategies to guide the system [38].

There are four types of strategies in this type of analysis;

a) The first type, internal strengths as compared with external opportunities and SO strategies are derived. In implementing this type of strategy, the system tries to exploit external opportunities using internal strengths.

b) The second type, internal weaknesses are compared with opportunities outside the organization and WO strategies are derived. The goal of this type of strategy is to improve internal weaknesses through the use of outside opportunities.

c) The third type: they are adopted when internal strengths are compared with external threats and ST strategies are derived. In implementing these types of strategies, efforts are being made to reduce or eliminate the effects of threats outside the organization.

d) The fourth type is WT strategies that are obtained by comparing internal weaknesses with external threats. This strategy aims to reduce internal weaknesses and avoid external threats [39].

Although, due to the unplanned expansion and rapid growth of cities as well as the increase in traffic, the need to pay attention to intelligent systems is essential and inevitable. Despite having the numerous benefits and opportunities in some countries, especially the developing countries, this transportation system has some weaknesses in the structure of its own governing system and management, which seems to be necessary to resolve these issues in order to find the intelligent transportation system and increase its efficiency. According to different conducted studies, the strengths, weaknesses, opportunities, and threats resulted from the transportation system in Birjand metropolitan were obtained in the SWOT model as shown in Tables 1-4. Finally, due to the use of the desired model as well as the analysis of weaknesses, strengths, opportunities, and threats using the SWOT strategic model, the strategies obtained to achieve the determined goals in an intelligent transport system of Birjand city were as the following in the Table 5.

The structure presented in this section for smart government in Birjand as shown in Figure 1 is a combination of Asia [40], Jimenez et al. [41] And Schnoll's [42] structures along with other important components. The proposed structure helps to identify the important needs and requirements to fulfill and deploy smart government. This structure includes two important layers that citizens are at the core of this structure for the main purpose of smart government is to improve the life quality of citizens through providing high-quality services, detecting the needs and their fulfillment, and collaborating and engaging actively with citizens in different fields. In [43] As mentioned, the proposed structure consists of two layers. The first layer includes three components of technology, data, and information supply and institutions, and the second layer includes the components of governance/politics, smart economy, infrastructures, smart community, and smart environment. Remarkably, the first layer consists of components that directly connect with the citizen, while the second layer includes components that, although are not directly related to the citizen, provide the appropriate framework to offer high-quality services and eliminate their needs and problems. All components of the proposed structure have mutual communication.

Table 1. Potentiometric strengths for intelligent transport systems

\begin{tabular}{lcccc}
\multicolumn{1}{c}{ Strengths } & Initial factor & A secondary factor & Rank & Final factor \\
\hline $\begin{array}{l}\text { Raising service and safety } \\
\begin{array}{l}\text { Experienced experts in the transportation } \\
\text { system sector }\end{array}\end{array}$ & 71 & 0.234 & 4 & 0.936 \\
$\begin{array}{l}\text { Terms and conditions supporting } \\
\text { intelligent transport system }\end{array}$ & 44 & 0.145 & 2 & 0.29 \\
$\begin{array}{l}\text { Training programs to improve the } \\
\text { capabilities of Intelligent transport }\end{array}$ & 64 & 0.211 & 3 & 0.633 \\
$\begin{array}{l}\text { system managers } \\
\text { Economic savings }\end{array}$ & 55 & 0.181 & 2 & 0.362 \\
\multicolumn{1}{c}{ Total } & 69 & 0.227 & 3 & 0.681 \\
& 303 & 1 & - & 2.902 \\
\hline
\end{tabular}


Table 2. Potentiometric threats for intelligent transport systems

\begin{tabular}{|c|c|c|c|c|}
\hline Strengths & Initial factor & A secondary factor & Rank & Final factor \\
\hline Raising service and safety & 71 & 0.234 & 4 & 0.936 \\
\hline $\begin{array}{l}\text { Experienced experts in the transportation } \\
\text { system sector }\end{array}$ & 44 & 0.145 & 2 & 0.29 \\
\hline $\begin{array}{l}\text { Terms and conditions supporting the } \\
\text { intelligent transport system }\end{array}$ & 64 & 0.211 & 3 & 0.633 \\
\hline $\begin{array}{l}\text { Training programs to improve the } \\
\text { capabilities of Intelligent transport system } \\
\text { managers }\end{array}$ & 55 & 0.181 & 2 & 0.362 \\
\hline Economic savings & 69 & 0.227 & 3 & 0.681 \\
\hline Total & 303 & 1 & - & 2.902 \\
\hline
\end{tabular}

Table 3. Potentiometric weaknesses for intelligent transport systems

\begin{tabular}{lcccc}
\multicolumn{1}{c}{ Weaknesses } & Initial factor & A secondary factor & Rank & Final factor \\
\hline $\begin{array}{l}\text { The bad situation of hardware systems } \\
\begin{array}{l}\text { The inappropriate situation of quantitative } \\
\text { and qualitative human resources, }\end{array}\end{array}$ & 59 & 0.238 & 4 & 0.952 \\
$\begin{array}{l}\text { specialized in ITS sector } \\
\begin{array}{l}\text { The lack of knowledge in private sector } \\
\text { about the benefits of developing intelligent } \\
\text { transport systems }\end{array}\end{array}$ & 49 & 0.198 & 3 & 0.594 \\
$\begin{array}{l}\text { The inappropriate situation of contractors } \\
\text { (consultants) experienced in developing }\end{array}$ & 42 & 0.170 & 2 & 0.34 \\
$\begin{array}{l}\text { and maintaining intelligent systems } \\
\text { The initial cost of purchasing these } \\
\text { systems }\end{array}$ & 43 & 0.174 & 2 & 0.348 \\
$\quad$ Total & 54 & 0.218 & 3 & 0.654 \\
\hline
\end{tabular}

Table 4. Potentiometric opportunities for intelligent transport systems

\begin{tabular}{lcccc}
\hline \multicolumn{1}{c}{ Opportunities } & Initial factor & A secondary factor & Rank & Final factor \\
\hline $\begin{array}{l}\text { The growth of the intelligent transportation } \\
\text { system and its development in Birjand city }\end{array}$ & 76 & 0.232 & 4 & 0.928 \\
$\begin{array}{l}\text { The viewpoint of chief officers in the } \\
\text { development of intelligent transport systems }\end{array}$ & 47 & 0.143 & 3 & 0.429 \\
$\begin{array}{l}\text { The increase in the safety of roads and the } \\
\text { decrease of accidents }\end{array}$ & 68 & 0.297 & 4 & 0.828 \\
$\begin{array}{l}\text { Lowering the amount of energy } \\
\text { Lowering the environmental effects of }\end{array}$ & 74 & 0.226 & 4 & 0.904 \\
transportation Total & 62 & 0.189 & 3 & 0.567 \\
\end{tabular}

Table 5. Potentiometric strategies for intelligent transport systems

\begin{tabular}{|c|c|}
\hline SO (competitive -invasive strategies) & WT (defensive strategies) \\
\hline $\begin{array}{l}\text { 1. Planning various seminars and gatherings to } \\
\text { justify and familiarize all authorities and } \\
\text { citizens with the potentials and efficiency of the } \\
\text { transport system } \\
\text { 2. Formulating fundraising strategies in the } \\
\text { smart } \\
\text { transport system }\end{array}$ & $\begin{array}{l}\text { 1. Lack of Development in traditional transport systems } \\
\text { 2. Encouraging people to participate in the development of smart } \\
\text { transport systems } \\
\text { 3. Training private sector and informing it about the interests } \\
\text { resulted from the investment in this sector }\end{array}$ \\
\hline WO (review strategy) & ST (diversification strategy) \\
\hline $\begin{array}{l}\text { 1. Improving hardware systems } \\
\text { 2. Training private sector and informing it about } \\
\text { the interests resulted from the investment in this } \\
\text { sector } \\
\text { 3. Training the skilled human force } \\
\text { 4. Improving software systems }\end{array}$ & $\begin{array}{l}\text { 1. Systematic view, the development of transport systems in line } \\
\text { with the objectives of an intelligent transport system } \\
\text { 2. Reviewing the experiences of different countries and using } \\
\text { their successful experiences } \\
\text { 3. Finding the reasons for the failure of this at different parts and } \\
\text { avoiding the repeats }\end{array}$ \\
\hline
\end{tabular}




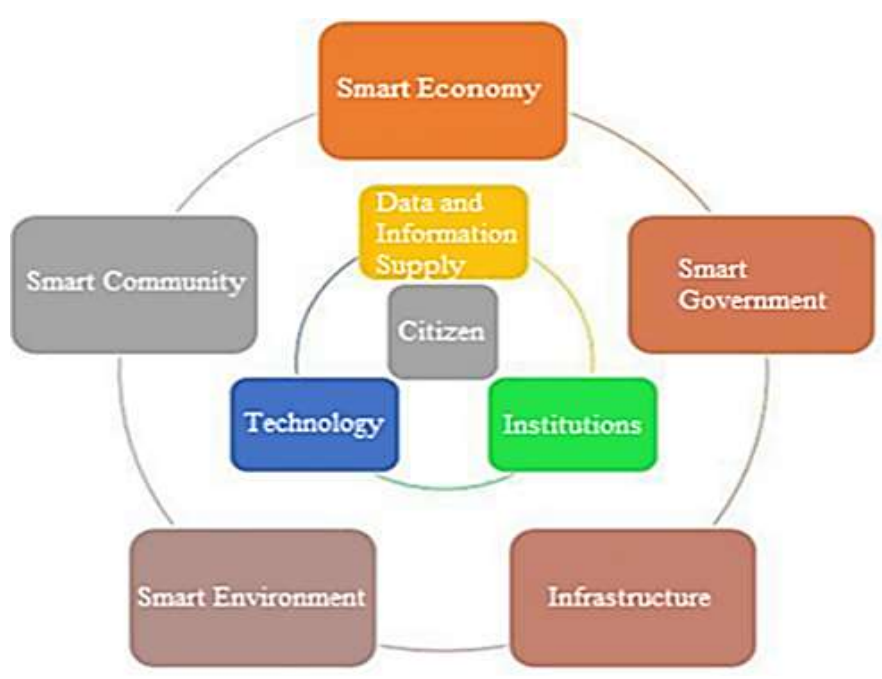

Figure 1. The proposed structure for smart government

\section{CONCLUSION}

The results of studies related to the two components of the intelligent transport system and smart government discussed in regard to transforming Birjand city to a smarter city are divided into two following parts. For potentiometric analysis, planning and providing the strategies necessary to create an intelligent transport system in Birjand city, internal and external factors were identified and some strategies were proposed using SWOT analysis method. After the analysis and comparison of this method, some strategies were proposed to use positive points and reduce the effects of negative points. Focusing on these strategies and making decisions by taking into account the mentioned factors can help to improve transport in this area. It seems that moving towards implementing strategies can overcome many transport problems in the city.

However, the following suggestions are presented to achieve the ultimate goal of the intelligent transportation system in this city. Training experts in the field of intelligent transportation in Birjand city. Organizing multiple briefing sessions for officials of different sectors to learn more about the results of using this system in the city. Reviewing and using successful experiences at the national and international level. Implementing basic studies and long-term strategies to develop the intelligent transport system. Expanding the partnership between the public sector and the private sector to use intelligent transportation

ITS activities in the world's major cities show the importance of these systems. The advantage of ITS both in terms of cost-benefit ratio and the nature of benefits is the main reason to use these systems. In America, for example, the cost-benefit ratio in urban areas is 5.2, and in large cities, it reaches 2.8. With the aim of identifying the needs and requirements of smart government deployment, at first, a comprehensive structure for the realization of smart government in Birjand city was addressed after reviewing the literature, extracting various features and structures of smart government and using the valuable ideas of experts in this field. The proposed structure consists of two layers and eight components that citizens are at the core. The three components of technology, data supply and application, and institutions in the first layer have direct interaction with citizens. The five components of governance/politics, smart economy, smart community, smart environment, and infrastructures are in the second layer. Although they are not directly related to citizens, they affect the way services are provided indirectly. In addition, their existence is a prerequisite for the realization of a smart government.

The structure presented in this study also addresses the various dimensions that governments should take into account in their activities and plans for the realization and deployment of smart government. The issues which need attention in smart government are the security and privacy due to government openness, the use of up-to-date technologies, the regulation of supportive laws and regulations, the reinforcement of the intellectual property system, the establishment of interactions and communications with other areas in the country and the enhancement of people knowledge and awareness. With the activities undertaken in the country for the realization of e-government, it can be stated that currently, our country is transitioning from the first generation of e-government (i.e. Information creation) to the second generation, namely Electronic transmission. Although it seems that we have a long way to go to the third generation, i.e. The smart $\mathrm{t}$ government, fortunately, the policies and laws that have been adopted in recent years can provide the necessary ground for the realization of the third generation. In addition, though there is a lack of policies and laws in some areas, it is hoped that the results of this study and other similar studies can attract the attention 
of policymakers to these issues. Based on the structure presented for smart government, the realization of such government is not limited to a specific field, but it requires the cooperation of all parts of society, institutions, and their appropriate interactions and relationships.

The policy recommendations and strategies that are the result of examining the policies and programs of the country in the field of e-government and can provide the necessary ground for the realization of smart government are as follows: designing architecture by a smart government and development policies, laws, and regulations in line with it. Defining smart government plans, according to its position in the reference architecture of smart government development. Holding various conferences and meetings of bulk data and its applications to become familiar with the concept and its application. Culture-building and designing programs to raise awareness and knowledge of the community, disseminating the culture of knowledge sharing, and encouraging all levels of society to use day-to-day technologies for their own activities by increasing accessibility and reducing the cost of these technologies.Increasing information transparency by adopting appropriate policies and monitoring the implementation of these policies and providing the necessary framework for implementing the relevant policies in this area. Increasing knowledge and information sharing between governmental agencies, as well as between governments, citizens and businesses, by providing the necessary framework for information exchange through various channels such as mobile phones to enhance openness. Considering the dimensions of environmental protection and sustainable development policies, laws and regulations related to the development of e-government and other laws. Providing the necessary infrastructures to increase information security and people privacy. Holding training courses for employees, citizens to increase their knowledge in the field of information technology and its approaches. Allocating budget to develop e-government and smart government and organize the budget allocation process.

Although many efforts have been made to achieve the results in this plan, to achieve better and more effective results, the following issues are suggested. Use the Internet of Objects. Use advanced technology such as high-quality smart cameras in the transportation system. Use the Internet of objects in security and privacy.

\section{REFERENCES}

[1] Barati Goudarzi N., \& Gharai F., "Regenerating the Spatial Patterns of Contemporary Neighborhoods in Tehran Based on Traditional Neighborhood Patterns by Examining the Evolution of Two Periods of Qajar And Contemporary," The Turkish Online Journal of Design, Art and Communication, pp. 75-94, 2016.

[2] B. Seyedashrafi, M. Ravankhah, et. al., "Applying heritage impact assessment to urban development: World heritage property of Masjed-e Jame of Isfahan in Iran," Sustainable Cities and Society, vol. 31, pp. 213-224, 2017.

[3] M. Noroozian, "The elderly population in Iran: an ever growing concern in the health system," Iranian Journal of Psychatry and Behavioral Science, vol. 6, no. 2, pp. 1-6, 2012.

[4] V. Albino, U. Berardi, and R. M. Dangelico, "Smart Cities: Definitions, Dimensions, Performance, and Initiatives," J. Urban Technol., vol. 22, no. 1, pp. 3-21, Jan. 2015.

[5] L. Bosek, "Information Sharing, Transparency, and E-Governance Among County Government Offices in Southeastern Michigan," 2017.

[6] M. Angelidou, "Smart city policies: A spatial approach," Smart city policies: A spatial approach, vol. 41, pp. S3-S11, 2014.

[7] F. Corno, T. Montanaro, "SmartBike: An IoT crowd sensing platform for monitoring city air pollution," International Journal Of Electrical And Computer Engineering, 2017.

[8] A. Auer, S. Feese, S. Lockwood, and B. Hamilton, "History of intelligent transportation systems," 2016. [Onine]. Available: https://www.its.dot.gov/presentations/2017/AVCV_ITSHistory.pdf

[9] Willhelm R., et. al., "The governance of smart cities: A systematic literature review," Cites, vol. 81, pp. 1-23, 2018.

[10] D. Mutiara, S. Yuniarti, and B. Pratama, "Smart governance for smart city," IOP Conf. Ser. Earth Environ. Sci., 2018.

[11] G. V. Pereira, M. A. Macadar, E. M. Luciano, and M. G. Testa, "Delivering public value through open government data initiatives in a Smart City context," Inf. Syst. Front., vol. 19, no. 2, pp. 213-229, Apr. 2017.

[12] C. Peprah, O. Amponsah, C. Oduro, "A system view of smart mobility and its implications for Ghanaian cities," Sustainable Cities and Society, vol. 44, pp. 739-747, 2019.

[13] M. Gohar, M. Muzammal, et. al., "SMART TSS: Defining transportation system behavior using big data analytics in smart cities," vol. 41, pp. 114-119, 2018.

[14] Khiabani A. G., \& Heydari A., "Design and implementation of an optimal switching controller for uninterruptible powersupply inverters using adaptive dynamic programming," IET Power Electronics, vol. 12, no. 12, 2019.

[15] Khiabani A. G., \& Heydari, A., "Optimal switching of voltage source inverters using approximate dynamic programming," In ASME 2018 Dynamic Systems and Control Conference (pp. V001T01A006-V001T01A006). American Society of Mechanical Engineers, 2012.

[16] Babazadeh R., \& Khiabani A. G., "Nonlinear Observer Design for RC Battery Model for Estimating State of Charge \& State of Health Based on State-Dependent Riccati Equation," In 2018 IEEE Electrical Power and Energy Conference (EPEC) IEEE, pp. 1-5, 2018.

[17] Azarang A., Kamaei S., Miri M., \& Asemani M. H., "A new fractional-order chaotic system and its synchronization via Lyapunov and improved Laplacian-based method," Optik, vol. 127, no. 24, pp. 11717-11731, 2016. 
[18] Azarang A., Ranjbar J., Mohseni H., \& Andy M. A., "Output feedback synchronization of a novel chaotic system and its application in secure communication," International Journal of Computer Science and Network Security, vol. 17, pp. 72-77, 2017.

[19] Azarang A., Miri M., Kamaei S., \& Asemani M. H., "Nonfragile fuzzy output feedback synchronization of a new chaotic system: design and implementation," Journal of Computational and Nonlinear Dynamics, vol. 13, no. 1, pp. 1-11, 2018.

[20] Mohamed R. M. R., Mohamed M. A., Ahmad A., \& Halim M. A. A., "Provisioning of street lighting based on ambience intensity for smart city," Indonesian Journal of Electrical Engineering and Computer Science, vol. 12, no. 3, pp. 1401-1406, 2018

[21] Achmad K. A., Nugroho L. E., \& Djunaedi A., "Smart City Readiness based on Smart City Council's Readiness Framework," International Journal of Electrical \& Computer Engineerin, vol. 8, no. 1, pp. 271-279, 2018.

[22] Subramanian J. V., \& Govindarajan S., "A Study of Mobile User Movements Prediction Methods," International Journal of Electrical and Computer Engineering, vol. 8, no. 5, pp. 3112-3117, 2018.

[23] Al-Rubaye M. J. M., Ali A., \& Chisab R., "A smart monitoring and controlling for agricultural pumps using LoRa IOT technology," Indonesian Journal of Electrical Engineering and Computer Science, vol. 13, no. 1, pp. 286-292, 2019.

[24] Pazhoohesh M., \& Zhang C., "Automated construction progress monitoring using thermal images and Wireless Sensor Networks," GEN 101-01, 2015.

[25] Pour M. S., Bou-Harb E., Varma K., Neshenko N., Pados D. A., \& Choo, K. K. R., "Comprehending the IoT cyber threat landscape: A data dimensionality reduction technique to infer and characterize Internet-scale IoT probing campaigns," Digital Investigation, vol. 28, pp. S40-S49, 2019.

[26] Safaei Pour M., \& Salmasizadeh M., "A new CPA resistant software implementation for symmetric ciphers with smoothed power consumption: SIMON case study," The ISC International Journal of Information Security, vol. 9, no. 2, pp. 119-130, 2017.

[27] Pour M. S., \& Bou-Harb E., "Implications of Theoretic Derivations on Empirical Passive Measurements for Effective Cyber Threat Intelligence Generation," In 2018 IEEE International Conference on Communications (ICC) IEEE, pp. 1-7, 2018.

[28] Zakershahrak, Mehrdad, Akshay Sonawane, Ze Gong, and Yu Zhang, "Interactive Plan Explicability in Human-Robot Teaming," In 2018 27th IEEE International Symposium on Robot and Human Interactive Communication (RO-MAN), IEEE, pp. 1012-1017, 2018.

[29] Shahrak, Mehrdad Zaker, Mengmei Ye, Viswanathan Swaminathan, and Sheng Wei, "Two-way real time multimedia stream authentication using physical unclonable functions," In Multimedia Signal Processing (MMSP), 2016 IEEE 18th International Workshop on IEEE, pp. 1-4, 2016.

[30] Zaker Shahrak, Mehrdad, "Secure And Lightweight Hardware Authentication Using Isolated Physical Unclonable Function," Computer Science and Engineering: Theses, Dissertations, and Student Research, 2016. [Online]. Available: https://digitalcommons.unl.edu/

[31] Nofeli F., \& Arabshahi H., "Electronic Transport Properties in Bulk ZnO and Zn1- xMgxO Using Monte Carlo Simulation," Global Journal of Science Frontier Research, vol. 15, no. 3, pp. 119, 2015.

[32] K. Achmad L., et al., "Smart City Readiness based on Smart City Council's Readiness Framework.," International Journal of Electrical and Computer Engineering (IJECE), vol. 8, no. 1, pp. 271-279, 2018.

[33] L. B. Bingham, T. Nabatchi, and R. O'Leary, "The New Governance: Practices and Processes for Stakeholder and Citizen Participation in the Work of Government," Public Adm. Rev., vol. 65, no. 5, pp. 547-558, Sep. 2005.

[34] C. C.-D., "The future of digital government," igi-global.com, 2004.

[35] M. Kurttila, M. Pesonen, J. Kangas, M. K.-F., "Utilizing the analytic hierarchy process (AHP) in SWOT analysisa hybrid method and its application to a forest-certification case," Forest Policy and Economics, vol. 1, no. 1, pp. 41-52, 2000.

[36] Scholl, H. J., \& Scholl, M. C., "Smart governance: A roadmap for research and practice," IConference 2014 Proceedings, 2014.

[37] H. Hekmatnia, "The role of transportation planning on physiological tissue modification in Tehran's area 8 using SWOT analysis model," Reg. urban Stud. Res., vol. 10, no. 3, pp. 95-110, 2011.

[38] A. P. Ahmad, M. Sarraf, N. H.-I. J., "Role of Urban Management in Cultural Events Economy of Academic Cities to Tourism Industry Development (Case Study: Kish Island)," ijumes.net, vol. 16, no. 4, pp. 19-28, 2017.

[39] M. Giaoutzi, "Tourism and regional development: New pathways, " Economic Geography Series, 2017.

[40] M. A.-P. A. in S. Asia and undefined 2016, "e-Government in India," content.taylorfrancis.com, 2016.

[41] C. Dolicanin, E. Kajan, D. Randjelovic, and B. Stojanovic, "Handbook of Research on Democratic Strategies and Citizen-Centered E-Government Services," 2015.

[42] H. Schnoll, "E-Government: Information, Technology, and Transformation: Information, Technology, and Transformation," 2015.

[43] L. Anthopoulos, C. R.-I. Polity, "Understanding electronic government research and smart city: A framework and empirical evidence," Information Polity, vol. 21, no. 1, pp. 99-117, 2016 